\title{
Ontogenic differences in the concentration of domoic acid in the digestive gland of male and female Octopus vulgaris
}

\author{
P. R. Costa*, J. Pereira \\ IPIMAR - National Institute of Biological Resources, Av. Brasília, 1449-006 Lisbon, Portugal
}

\begin{abstract}
Domoic acid (DA), a neurotoxin produced by the diatom genus Pseudo-nitzschia, has been recently found to accumulate in Octopus vulgaris. To elucidate inter-animal variation in DA concentration in octopus digestive glands and its relation to biometric (size and body mass) and biological (sex and maturity) parameters, 54 specimens were caught in the same fishing area during a bloom of toxic plankton. Toxin concentration in female octopuses, as determined by liquid chromatography, was significantly inversely correlated with octopus mantle length $\left(\mathrm{r}^{2}=0.63\right)$, body mass $\left(r^{2}=0.62\right)$ and weight of the digestive gland $\left(r^{2}=0.55\right)$. A tendency for decreasing DA concentration with maturity stages was also observed in females. No significant correlation was observed between DA concentration and any biometric or biological parameter of male specimens. Negative correlations during periods of toxin uptake suggest that younger female octopuses are greater consumers of toxic prey and represent a higher threat as DA vectors in the marine food web.
\end{abstract}

KEY WORDS: Amnesic shellfish poisoning $\cdot$ Cephalopods $\cdot$ Sex $\cdot$ Size $\cdot$ Food web

\section{INTRODUCTION}

Marine toxins produced by phytoplankton species are traditionally associated with filter-feeding bivalves which are the main vectors causing human poisoning. However, non filter-feeding organisms can also accumulate marine toxins through complex trophic interrelations. Cephalopods play a central role in the marine food web. They are active predators, with high growth and metabolic rates, feeding on a large range of live prey, and are also important in the diets of top predators. Their role as predators of filter-feeding bivalves would suggest that cephalopods might be potential vectors of marine toxins. In fact, domoic acid (DA) has been found in their tissues, with noticeable concentrations detected in the digestive gland (Costa et al. 2004, 2005a,b).

DA, the main toxin responsible for the human illness amnesic shellfish poisoning (ASP), is mostly produced by the diatom species Pseudo-nitzschia australis on the Portuguese coast (Costa \& Garrido 2004). Their blooms are related to upwelling events occurring predominantly in spring and early summer (Moita 2001). DA levels are recurrently monitored in bivalve molluscs. However, they only occasionally exceed the EU regulatory limit $\left(20 \mu \mathrm{g} \mathrm{DA} \mathrm{g}^{-1}\right)$ stated for safe human consumption. This toxin binds to glutamate receptors in specific regions of the brain (especially the hippocampus), causing destructive neuronal depolarization (Debonnel et al. 1989) and permanent short-term memory loss in mammals (Perl et al. 1990, Todd 1993). Harvesting closures due to DA contamination are not frequent and are characterized by small periods that last no more than 2 wk (Vale et al. 2008). Nevertheless, cephalopods have consistently shown high DA concentrations $\left(>20 \mu \mathrm{g} \mathrm{g}^{-1}\right)$ accumulated in their tissues. Several routes for DA contamination of cephalopods and benthic communities have been suggested (Costa et al. 2005a, Vigilant \& Silver 2007), not unlike those suggested for the high levels of essential and nonessential elements also known to accumulate in cephalopod tissues (e.g. Raimundo et al. 2005). 
The present study assessed the inter-animal variability of DA concentrations in the digestive gland of octopus Octopus vulgaris. Knowledge on the variation in toxin levels among individuals is of ecological and physiological relevance and important for environmental management. Several factors contributing to inter-animal variability in DA concentration should be considered: magnitude, persistence and exposure of octopus prey to toxic phytoplankton, geographical location, water depth and currents, body mass/mantle length and differences in octopus feeding rates. To minimise variability, a number of octopuses collected on the same fishing trip and in the same fishing area were used for the quantification of DA concentration in the digestive gland, and its relation to biometric and biological parameters, such as body mass, mantle length, sex and maturity stage was evaluated.

\section{MATERIALS AND METHODS}

Octopus sampling and tissue preparation. A total of 54 specimens of Octopus vulgaris were captured when blooms of the diatom Pseudo-nitzschia were identified and DA recorded in natural beds of clams by the Portuguese monitoring program for toxic algae and marine toxins (National Institute of Biological ResourcesIPIMAR). The specimens were captured at a depth range of 25 to $35 \mathrm{~m}$ by a commercial trawler in the fishing area off Peniche (northwest Portuguese coast) on 1 June 2007. All octopus specimens were kept at $-20^{\circ} \mathrm{C}$ for a maximum of $2 \mathrm{wk}$ before dissection, which was carried out under partially defrosted conditions and without rupture of the outer membrane of the organs in order to minimize DA leakage. For each animal the following parameters were recorded: body weight, mantle length and digestive gland weight. Four maturity stages were determined using the scale proposed by Mangold-Wirz (1963). Digestive glands were dissected, homogenized and $5 \mathrm{~g}$ aliquots used for analysis.

Toxin extraction and high performance liquid chromatography analysis. Extractions were carried out following the method of Quilliam et al. (1995). High performance liquid chromtography (HPLC) was performed on a Hewlett-Packard (HP) Model 1100 equipped with inline degasser, quaternary pump, autosampler, oven and diode-array detector. Data collection and treatment of results were performed by the HP Chemstation software. The column used was a Nucleosil 100-5C-18 (125 × $3 \mathrm{~mm}, 5 \mu \mathrm{m})$ with a guard-column Lichrospher $100 \mathrm{RP}-18(4 \times 4 \mathrm{~mm}, 5 \mu \mathrm{m})$, both heated to $40^{\circ} \mathrm{C}$. The flow rate was set at $0.45 \mathrm{ml} \mathrm{min} \mathrm{m}^{-1}$ of acetonitrile:0.1\% formic acid (10:90, v/v) throughout the run. The injection volume was $5 \mu \mathrm{l}$ and analysis time was set at $10 \mathrm{~min}$. Detection wavelength was set at $242 \mathrm{~nm}$ with a $10 \mathrm{~nm}$ bandwidth, and reference wavelength was set at $450 \mathrm{~nm}$ with a $100 \mathrm{~nm}$ bandwidth. Calibration was performed with a full set of calibration standards of DA $\left(0.5,2,4\right.$ and $\left.10 \mu \mathrm{g} \mathrm{ml}^{-1}\right)$. Samples over the calibration curve were diluted. Calibration curves were always linear, with correlation coefficients $>0.99$. A single point calibration, with a working solution of $4 \mu \mathrm{g} \mathrm{ml}^{-1} \mathrm{DA}$ in $10 \%$ acetonitrile, was performed after 6 consecutive samples. Under these conditions the detection limit was $0.04 \mu \mathrm{g} \mathrm{ml}^{-1}$, corresponding to $0.2 \mu \mathrm{g} \mathrm{g}^{-1}$ in tissue.

For HPLC analysis Millipore-Q cleaned water and LC grade methanol and acetonitrile supplied by Merck were used. DACS-1D certified DA standard was purchased from the National Research Council of Canada.

Statistical analysis. The Mann-Whitney $U$-test was applied for comparisons of toxin determined in the digestive glands of female and male specimens.

Data on toxins in the digestive gland were analysed as a function of mantle size and body mass with model II linear regressions since these variables are subject to natural variation (Sokal \& Rohlf 1995). Toxin concentration data were log-transformed to achieve a normal distribution.

\section{RESULTS}

Of the 54 octopus specimens captured, 33 were females and 21 were males, ranging in size, body mass and maturity (Table 1). DA was consistently found in each octopus specimen (Fig. 1). Highly variable concentrations of DA (coefficient of variation of $92 \%$ ) were determined in the digestive gland of female (1.5 to $124 \mu \mathrm{g} \mathrm{g}^{-1}$ ) and male (2.1 to $92 \mu \mathrm{g} \mathrm{g}^{-1}$ ) octopuses. No significant differences $(p>0.05)$ in DA concentrations were found between sexes.

Despite the observed elevated variability, a significant relation between DA concentration and both size and body mass of octopus was discovered. DA concentrations determined in the digestive gland decreased significantly ( $p<0.001)$ with size (mantle length) and body mass (weight), with these 2 variables explaining 63 and $62 \%$, respectively, of the variability in logtransformed DA concentration for female specimens

Table 1. Octopus vulgaris. Biometric (body weight [BW], mantle length [ML]) and biological (sex, maturity) parameters of octopus specimens caught on 1 June 2007 in Peniche (NW Portuguese coast)

\begin{tabular}{|lccccccc|}
\hline Sex & $\mathrm{n}$ & BW (g) & ML (mm) & \multicolumn{4}{c|}{ Maturity (\% of specimens) } \\
& & min-max & min-max & Stage 1 & Stage 2 & Stage 3 & Stage 4 \\
\hline Female & 33 & $816-4058$ & $130-250$ & 9 & 64 & 24 & 3 \\
Male & 21 & $799-2150$ & $125-195$ & 0 & 67 & 33 & 0 \\
\hline
\end{tabular}




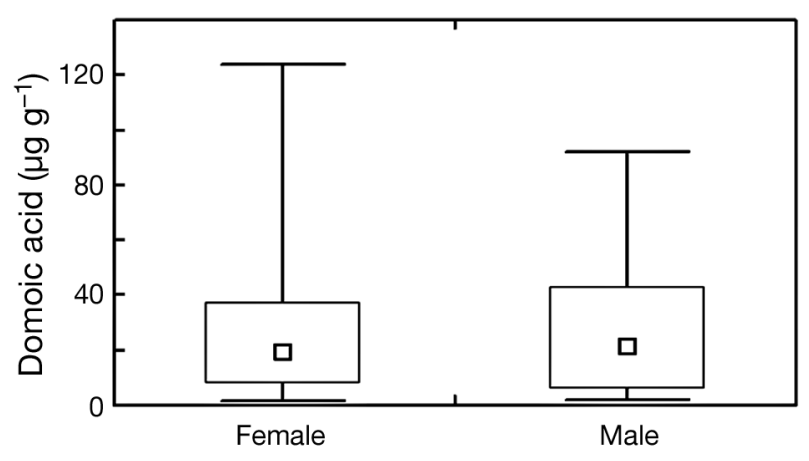

Fig. 1. Octopus vulgaris. Domoic acid concentration (median, 25 and 75 quartiles, minimum and maximum) determined in the digestive gland of female $(n=33)$ and male $(n=21)$ octopuses caught in Peniche (NW Portuguese coast) on 1 June 2007

(Fig. 2a,c). The weight of the digestive gland, which is positively correlated to octopus size $\left(\mathrm{r}^{2}=0.61\right.$, data not shown) and body mass $\left(\mathrm{r}^{2}=0.66\right.$, data not shown), explained $55 \%$ of the variability in log-transformed DA concentration for females (Fig. 2e). The same was not shown for males (mantle length, $\mathrm{r}^{2}=0.05$; body mass, $r^{2}=0.07$; weight of digestive gland, $r^{2}=0.02$; Fig. 2b, d, f).
Although not as significant as the changes in DA concentrations, a negative correlation between logtransformed toxin burden (absolute amounts) and animal size was found for female specimens (Fig. 3).

From the application of the maturity scale developed by Mangold-Wirz (1963), the great majority of octopuses were found to be in Stages II and III. There were a few immature (Stage I) females and 1 mature Stage IV female. Males were found in maturity Stages II and III. Maturity was shown to generally increase with mantle length, in spite of the characteristic cephalopod overlap of mantle lengths between maturity stages (Fig. 4). Therefore, a significant relation between growth and maturity was not apparent and thus only a non-significant tendency was observed for the relation between maturity stages and the log-transformed DA concentration in the digestive gland of female specimens (Fig. 5).

\section{DISCUSSION}

DA was detected in each octopus specimen subjected to the same environmental conditions. Due to natural variability of DA in octopus prey and octopus
Fig. 2. Octopus vulgaris. Logtransformed DA concentration in the digestive gland of female $(\bullet$, $\mathrm{n}=33)$ and male $(\Delta, \mathrm{n}=21)$ octopuses as a function of $(\mathrm{a}, \mathrm{b})$ mantle length, (c, d) body weight and $(\mathrm{e}, \mathrm{f})$ digestive gland weight

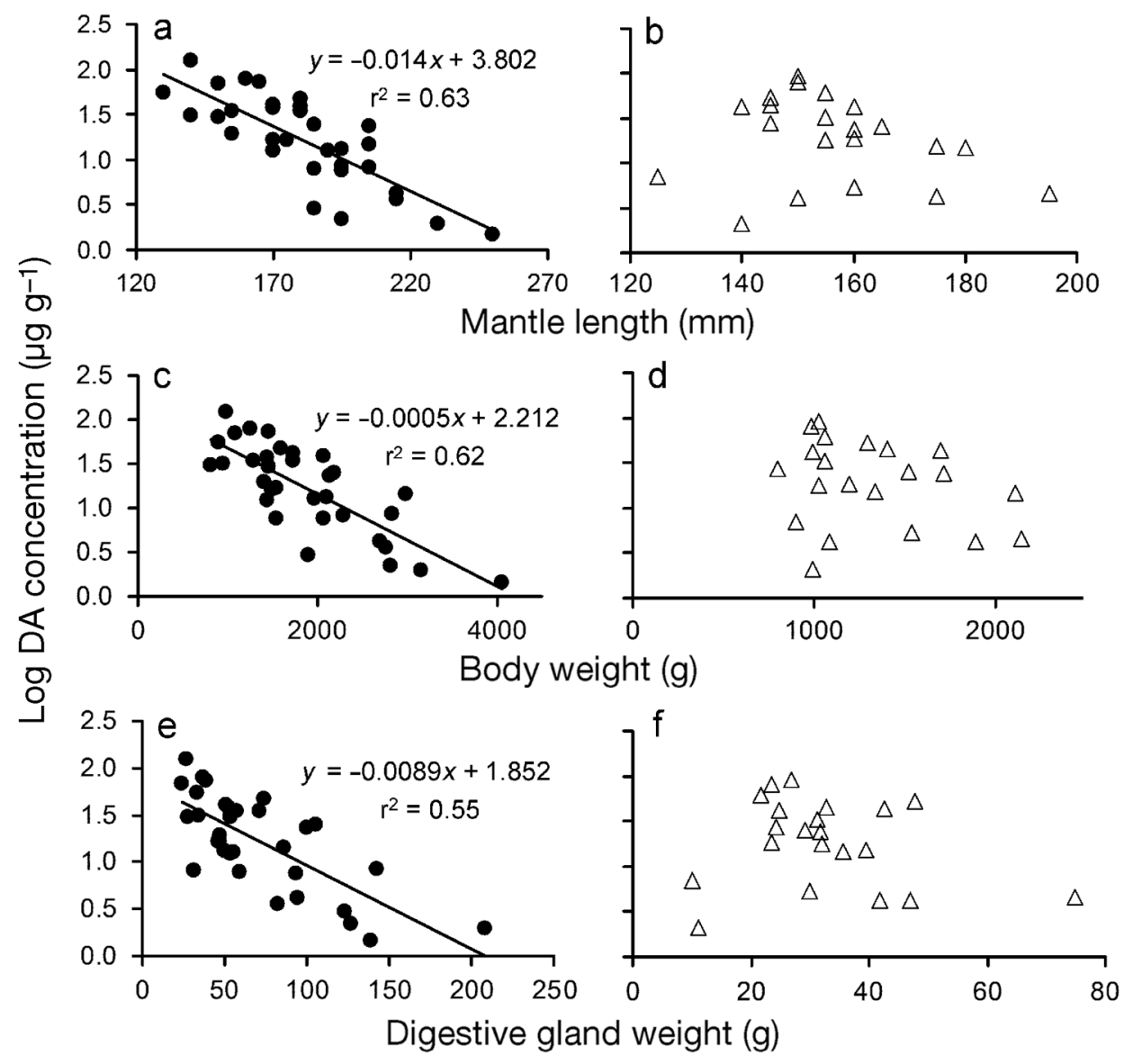




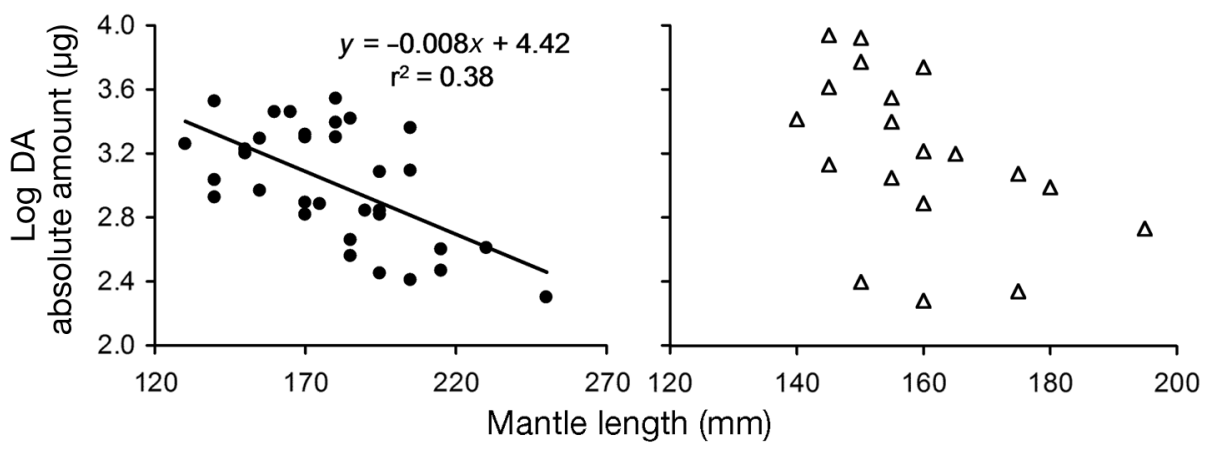

Fig. 3. Octopus vulgaris. Logtransformed DA absolute amount $(\mu \mathrm{g})$ per digestive gland of female $(\bullet, \mathrm{n}=33)$ and male $(\Delta$, $\mathrm{n}=21$ ) octopuses as a function of mantle length feeding rates, a high heterogeneity of DA concentrations determined in the octopus digestive gland was expected and confirmed by the coefficient of variation of $92 \%$. Nevertheless, after specimens were grouped by sex, DA concentrations were found to decrease with increasing body size (mantle length) in females. Body weight and digestive gland weight were also negatively correlated to DA, as they are not independent of size. Assessment of maturation in cephalopods usually involves the qualitative evaluation of several aspects of the reproductive development of the species, and is most frequently described with the support of numerical scales made up of recognizable quantitative stages (Boyle \& Rodhouse 2006). Although these data in the present study were provided by qualitative morphological observations, determination of quantitative relationships were possible, which show a trend for decreasing DA concentrations with increasing maturity stages.

Octopus feeding rates are known to decrease with size, which leads to younger octopuses growing proportionally faster than older ones (García \& Giménez 2002). A study on the relationship between the length of prey selected in the field and octopus size has shown smaller octopuses preying on smaller mussel size classes (Smale \& Buchan 1981). Since higher toxin concentrations have been found in smaller mussels than in

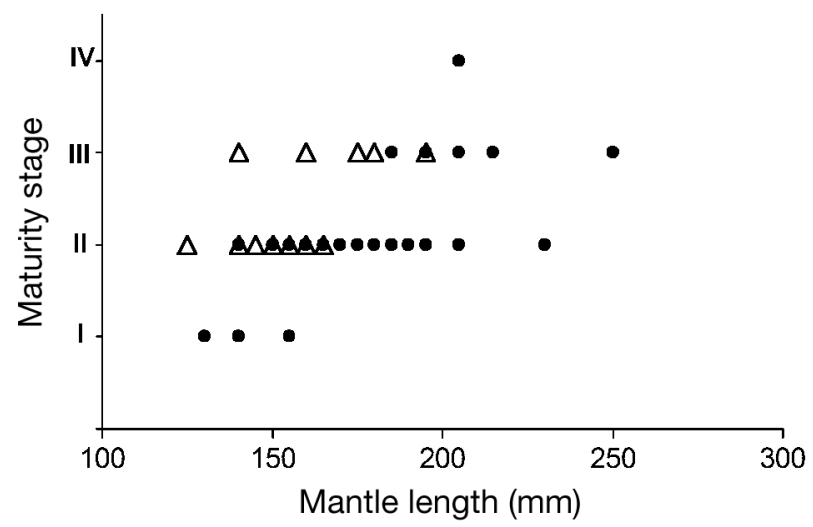

Fig. 4. Octopus vulgaris. Relation between mantle length and maturity stages in female $(\bullet)$ and male $(\Delta)$ octopuses large ones (Novaczek et al. 1992, Morono et al. 2001), octopus feeding behaviour will also contribute to the accumulation of higher DA values in smaller specimens. In terms of the toxin burden, higher amounts of DA were also found in smaller octopus specimens. Smaller octopuses that have higher feeding rates should therefore consume a higher number of mussels of smaller size which are more contaminated.

The influence of size on DA concentration has been studied for other molluscs such as the king scallop Pecten maximus (Bogan et al. 2007), where it was shown to negatively affect DA concentration only during blooms of toxic plankton (period of toxin uptake). Our observations suggest that during the algal bloom, the accumulation of DA in the predator Octopus vulgaris is similar to that of the filter feeder $P$. maximus.

In the present study, a negative correlation between DA concentrations and animal size and body weight was only exhibited by females. A possible explanation is the fact that the smaller number of male specimens, as well as their smaller range of size, body weight and maturity stage, may not allow similar significant correlations. However, several authors have observed higher growth and feeding rates and food conversion for octopus females than males, due to higher energy demands of the female development (Smale \& Buchan 1981, Domain et al. 2000, García \& Giménez 2002,

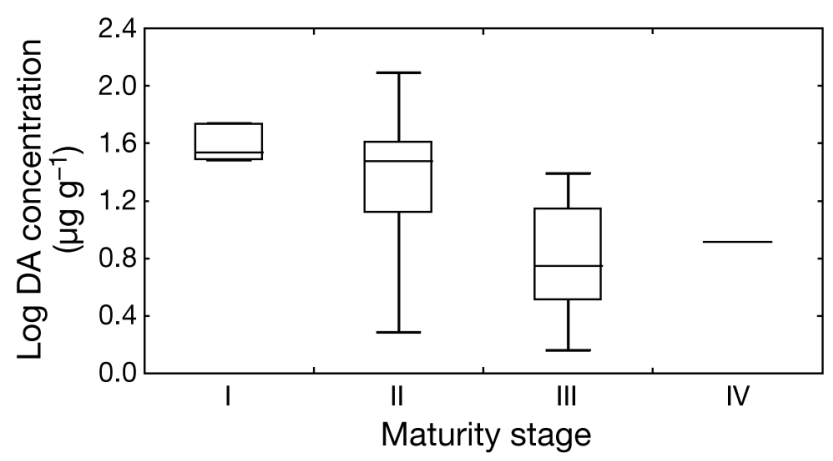

Fig. 5. Octopus vulgaris. Log-transformed DA concentration determined in the digestive gland of female octopuses in different maturity stages (median, 25 and 75 quartiles, minimum and maximum, total $\mathrm{n}=33$ ) 
Giménez \& García 2002). Thus feeding dynamics of females should be more regular and intense. Previous research has shown that the biochemical composition of the digestive gland seems not to be influenced by sexual maturation but rather by biotic factors, namely feeding activity and food availability (Rosa et al. 2004), which further supports the hypothesis that differences in the feeding regime of males and females and between younger and older specimens may be responsible for the different patterns of DA concentration found in the species.

The digestive gland is the largest octopus organ (only surpassed by the female gonads at the peak of maturity), representing on average $4 \pm 1 \%$ of the total body mass of specimens caught in the present study. The concentration of toxin in the whole octopus body can be estimated applying a 25 -fold dilution to the DA concentration determined in the digestive gland. Nevertheless, this value will be underestimated due to the concomitant accumulation of DA in other organs such as branchial hearts, kidney, stomach and intestine (Costa et al. 2004). The total amount of DA in the whole octopus body can be a valuable parameter for evaluation of the potential risk of this seafood for human consumption. Although human consumption of this seafood is usually limited to larger and eviscerated animals, human health hazards may be expected from the consumption of whole small octopuses as a delicacy (a custom in southwestern European and Mediterranean countries).

We conclude that after toxic blooms and contamination of the benthic communities, younger octopuses (and notably female specimens) are expected to accumulate the highest levels of DA and therefore represent potential toxin vectors in the marine food web.

Acknowledgements. The Portuguese Foundation for Science and Technology (FCT) supported this study through a postdoctoral grant to P.R.C. The authors greatly appreciate the technical assistance of P. da Conceição. We also thank J. Raimundo for the helpful comments on the manuscript.

\section{LITERATURE CITED}

Bogan YM, Harkin AL, Gillespie J, Kennedy DJ, Hess P, Slater JW (2007) The influence of size on domoic acid concentration in king scallop, Pecten maximus (L.). Harmful Algae 6:15-28

Boyle P, Rodhouse P (2006) Cephalopods: ecology and fisheries, 2nd edn. Blackwell Science, Oxford

Costa PR, Garrido S (2004) Domoic acid accumulation in the sardine Sardina pilchardus and its relationship to Pseudonitzschia diatom ingestion. Mar Ecol Prog Ser 284:261-268

Costa PR, Rosa R, Sampayo MAM (2004) Tissue distribution of the amnesic shellfish toxin, domoic acid, in Octopus vulgaris from the Portuguese coast. Mar Biol 144:971-976

Costa PR, Rosa R, Pereira J, Sampayo MAM (2005a) Detection

Editorial responsibility: Ricardo Cattaneo-Vietti,

Genova, Italy of domoic acid, the amnesic shellfish toxin, in the digestive gland of Eledone cirrhosa and E. moschata (Cephalopoda, Octopoda) from the Portuguese coast. Aquat Living Resour 18:395-400

Costa PR, Rosa R, Duarte-Silva A, Brotas V, Sampayo MAM (2005b) Accumulation, transformation and tissue distribution of domoic acid, the amnesic shellfish poisoning toxin, in the common cuttlefish, Sepia officinalis. Aquat Toxicol 74:82-91

Debonnel G, Beauchesne L, Demontigny C (1989) Domoic acid, the alleged mussel toxin, might produce its neurotoxic effect through kainate receptor activation: an electrophysiological study in the rat dorsal hippocampus. Can J Physiol Pharmacol 67:29-33

Domain F, Jouffre D, Caverivere A (2000) Growth of Octopus vulgaris from tagging in Senegalese waters. J Mar Biol Assoc UK 80:699-705

García BG, Giménez FA (2002) Influence of diet on ongrowing and nutrient utilization in the common octopus (Octopus vulgaris). Aquaculture 211:171-182

Giménez FA, García BG (2002) Growth and food intake models in Octopus vulgaris Cuvier (1797): influence of body weight, temperature, sex and diet. Aquac Int 10:361-377

Mangold-Wirz K (1963) Biologie des Céphalopodes benthiques et nectoniques de la Mer Catalane. Vie Milieu 13: $1-285$

Moita MT (2001) Estrutura, variabilidade e dinâmica do fitoplâncton na costa de Portugal continental. PhD thesis, University of Lisbon

> Morono A, Franco J, Miranda M, Reyero MI, Blanco J (2001) The effect of mussel size, temperature, seston volume, food quality and volume-specific toxin concentration on the uptake rate of PSP toxins by mussels (Mytilus galloprovincialis Lmk). J Exp Mar Biol Ecol 257:117-132

Novaczek I, Madhyastha MS, Ablett RF, Donald A, Johnson G, Nijjar MS, Sims DE (1992) Depuration of domoic acid from live blue mussels (Mytilus edulis). Can J Fish Aquat Sci 49:312-318

> Perl TM, Bedard L, Kosatsky T, Hockin JC, Todd ECD, Remis RS (1990) An outbreak of toxic encephalopathy caused by eating mussels contaminated with domoic acid. N Engl J Med 322:1775-1780

Quilliam MA, Xie M, Hardstaff WR (1995) Rapid extraction and cleanup for liquid-chromatographic determination of domoic acid in unsalted seafood. J AOAC Int 78:543-554

Raimundo J, Pereira P, Vale C, Caetano M (2005) Fe, Zn, Cu and $\mathrm{Cd}$ concentrations in the digestive gland and muscle tissues of Octopus vulgaris and Sepia officinalis from two coastal areas in Portugal. Cienc Mar 31:243-251

$>$ Rosa R, Costa PR, Nunes ML (2004) Effect of sexual maturation on the tissue biochemical composition of Octopus vulgaris and O. defflippi (Mollusca: Cephalopoda). Mar Biol 145:563-574

> Smale MJ, Buchan PR (1981) Biology of Octopus vulgaris off the east coast of South Africa. Mar Biol 65:1-12

Sokal RR, Rohlf FJ (1995) Biometry: the principles and practice of statistics in biological research, 3rd edn. WH Freeman, New York, NY

Todd ECD (1993) Domoic acid and amnesic shellfish poisoning: a review. J Food Prot 56:69-83

> Vale P, Botelho MJ, Rodrigues SM, Gomes SS, Sampayo MAD (2008) Two decades of marine biotoxin monitoring in bivalves from Portugal (1986-2006): a review of exposure assessment. Harmful Algae 7:11-25

Vigilant VL, Silver MW (2007) Domoic acid in benthic flatfish on the continental shelf of Monterey Bay, California, USA. Mar Biol 151:2053-2062

Submitted: November 16, 2009; Accepted: April 20, 2010

Proofs received from author(s): May 20, 2010 